\title{
Cooperação financeira no Mercosul e o financiamento do investimento
}

Simone S. de Deos professora do Instituto de Economia da Unicamp (IE/Unicamp) e pesquisadora do Centro de Estudos de Relaçóes Econômicas Internacionais (CERI/IE/Unicamp)

Ana Rosa Ribeiro de Mendonça professora do IE/Unicamp e pesquisadora do Núcleo de Economia Industrial e da Tecnologia (NEIT/IE/Unicamp) e do CERI

Rubia C. Wegner professora do Departamento de Economia da Universidade Federal Rural do Rio de Janeiro (UFRRJ) e pesquisadora do CERI

\section{Palavras-chave}

Mercosul, sistemas financeiros, cooperação financeira regional, financiamento do investimento.

\section{Classificação JEL F33, F36,} F42.

\section{Keywords \\ Mercosur, financial systems, regional financial cooperation, investment financing.}

JEL Classification F33, F36, F42.

\section{Resumo}

Os esquemas de integração regional construídos ao longo da década de 1990, entre os quais o Mercosul, foram implementados em um contexto marcado pelo processo mais amplo de globalização financeira. A conexão dos países periféricos ao circuito da globalização financeira, contudo, não resolveu os problemas crônicos de falta de recursos para o financiamento de longo prazo. A literatura marcada pela tradição de Keynes aponta que a insuficiência de recursos de longo prazo (funding) para financiar o investimento é um problema crucial. Nesse sentido, o sistema financeiro deve ser capaz de prover recursos, especialmente de longo prazo, para financiar o investimento, minimizando a incerteza e viabilizando a aquisição dos ativos de capital de longo prazo de maturação. Neste artigo, objetiva-se analisar a importância da cooperação financeira regional para o fomento de mecanismos de financiamento de longo prazo nas economias do Mercosul.

\section{Abstract}

The regional integration systems that arose during the 1990s, such as Mercosur, were implemented during the so called financial globalization period. However, the connection of the economies in the periphery to the international financial markets has not been able to solve the key question of long term financing for investment. The literature in the Keynes tradition points out that the shortage of long term funding is a key problem. In this regard, the financial system should be able to provide resources, especially long term resources, for investment funding, minimizing uncertainty and making it feasible to acquire capital assets with longer maturities. This paper aims to analyze the importance of regional financial cooperation to strengthen the long term financing mechanisms in the Mercosur economies. 


\section{1_Introdução}

Os esquemas de integração regional construídos ao longo da década de 1990, tal como o Mercosul, foram concebidos e implementados em um contexto marcado pelo processo mais amplo de globalização financeira. Nessa perspectiva, o suposto era que a combinação de liberalização dos mercados e desregulamentação financeira promoveria a integração das economias periféricas com os mercados financeiros internacionais, de modo a resolver seus problemas estruturais de financiamento de longo prazo e a vulnerabilidade externa. Contudo, muitos autores apontam que a conexão dos países periféricos ao circuito da globalização financeira, com a abertura crescente das suas contas de capital e dos seus sistemas financeiros, não resolveu os problemas crônicos de falta de recursos para financiar o desenvolvimento (Amado; Silva, 2000).

A literatura de tradição keynesiana aponta, como se sabe, o investimento como variável de gasto fundamental para a determinação do emprego e renda. Dessa forma, a existência de mecanismos que viabilizem o financiamento das decisóes de investimento são fundamentais. Vale notar que é a insuficiência de recursos de longo prazo (funding) para financiar o investimento, e não a insuficiência de pou- pança, o problema crucial. Neste sentido, a existência de um sistema capaz de financiar adequadamente os investimentos reduz a incerteza. E deve-se ressaltar que, nos países da periferia do sistema, nos quais a instabilidade macroeconômica é mais acentuada, e os mercados financeiros menos desenvolvidos, a incerteza e a preferência pela liquidez - que tende a encurtar os prazos dos ativos e dos passivos financeiros - são mais exacerbadas (Mollo; Amado, 2001).

Iniciativas de cooperação financeira observadas no Sudeste da Ásia, após a crise da segunda metade dos anos 1990, podem ser entendidas como mecanismos para a superação de entraves para o desenvolvimento. Tais iniciativas estariam associadas à percepção mais recente de que a integração regional deve também buscar reduzir os riscos associados à abertura de suas economias. A percepção desse papel tem fomentado o debate entre autores de tradição keynesiana no que diz respeito ao estreitamento das relaçóes financeiras entre as economias do Mercosul. Afinal, a cooperaçáo financeira regional, em certa medida, poderia complementar a arquitetura financeira internacional (Cunha; Bichara, 2005). Dessa forma, o aprofundamento da interdependência entre os países por meio de blocos regionais reforça o argumento a favor de políticas e 
instituições capazes de contribuir para fomentar o desenvolvimento econômico e proteger as regióes de crises financeiras. Ademais, num contexto internacional de elevada instabilidade financeira e crises recorrentes, o papel da integração, especialmente em economias periféricas, para prover o financiamento de longo prazo e reduzir a vulnerabilidade externa, assume importância crescente.

Embora não se possa afirmar que a visão liberal de regionalismo vigente na década anterior tenha sido superada, nota-se, a partir de 2003, que os países sul-americanos passaram a tratar da integraçáo regional com objetivos que não apenas os comerciais (Couto, 2007). Dessa manei- ra, um conjunto de medidas importantes, tanto para prover o financiamento de longo prazo quanto para minimizar as diferenças estruturais entre seus membros, ganhou espaço na agenda regional. Além disso, a ideia da integração sul-americana se fortaleceu ${ }^{1}$ desde então, com iniciativas tais como a criação da União Sul-Americana das Naçóes (Unasul - 2008) ${ }^{2}$ e com a Iniciativa para a Integraçáo da Infra-Estrutura Regional Sul-Americana $\left(\right.$ IIRSA - 2000) ${ }^{3}$.

No âmbito da IIRSA, destaca-se a atuação da Corporaçáo Andina de Fomento (CAF), banco sub-regional de desenvolvimento, e do Fundo Financeiro para o Desenvolvimento da Bacia do Prata (Fonplata)

\footnotetext{
${ }^{1}$ Observa-se um

aprofundamento dessa ideia com o evoluir das reunióes entre os países sul-americanos - iniciadas em 2000. Como aponta Couto (2010, p. 25), o objetivo seria: "Construir um bloco sul-americano que possa fazer sentido além do seu significado geofísico, desenhando uma região política, econômica e socialmente integrada”.

${ }^{2} \mathrm{O}$ Tratado Constitutivo da Unasul foi assinado em maio de 2008, em Brasília. Sua origem, porém, é anterior a essa data, uma vez que,
}

em dezembro de 2004, foi assinada a Declaração de Cuzco, a qual anunciou a criação da Comunidade SulAmericana de Naçôes (Casa). $\mathrm{Na}$ reunião de CochabambaBolívia, em 2006, os países sul-americanos definiram que esta passaria a chamar-se União das Naçôes SulAmericanas (Unasul).

${ }^{3}$ A IIRSA teve origem na Reunião de Presidentes da América do Sul, realizada em agosto de 2000, em Brasília, na qual se acordou realizar açóes conjuntas para avançar na modernização da infraestrutura regional e na adoçâo de açóes específicas para promover sua integraçáo. É uma iniciativa dos 12 países sul-americanos. $\mathrm{O}$ Comitê de Coordenação Técnica, formado por BID, CAF e FONPLATA, foi responsável pela definição dos projetos de investimento de infraestrutura, bem como por sua organização em nove eixos de integraçáo e desenvolvimento (EID), em conformidade com a metodologia adotada de planificação territorial da América do Sul . Em 2009, os países da UNASUL criaram o
Conselho Sul-Americano de Infraestrutura e Planejamento (COSIPLAN), substituindo a IIRSA na direção executiva da integração física da América do Sul. Buscou-se, assim, conduzir a integração da infraestrutura com maior respaldo político, para assegurar a execução de investimentos em projetos prioritários com fontes de financiamento adequadas. A IIRSA foi mantida, mas na forma de um foro de articulação de informações técnicas sobre a elaboração e execução de projetos. 
no financiamento de projetos em áreas de infraestrutura, bem como no apoio técnico à execução desses. CAF e Fonplata foram ambas criadas nos anos 1970, para apoiar a integração econômica regional com vistas a promover o desenvolvimento econômico. Já o Fundo para a Convergência Estrutural e Fortalecimento da Estrutura Institucional do Mercosul (Focem), em operação desde 2007, tem como objetivo a redução das disparidades estruturais entre as economias do Mercosul, por meio do financiamento de investimentos.

$\mathrm{Na}$ dimensão da cooperação financeira regional voltada para minimizar a vulnerabilidade externa, estáo instituiçóes como o Sistema de Pagamentos em Moeda Local (SML, 2008), o Fundo Latino-Americano do Reservas (FLAR, 1978) e o Convênio de Pagamentos e Créditos Recíprocos (CCR, 1965). No que tange ao manejo da liquidez externa, a relevância dessas instituições é notável em situaçôes de ruptura ou deterioração das condiçóes de financiamento, uma vez que:

“...] mercados (financeiros) liberalizados podem significar estruturas financeiras frágeis, entradas e saídas pró-cíclicas de capital e redução dos investimentos de longa duraçâo" (Mollo; Amado, 2001, p. 136).

Dessa forma, fortalecem o sentido da cooperação financeira regional na medida em que complementam as instituições voltadas para o financiamento do investimento.

O presente trabalho tem como objetivo analisar a importância da cooperação financeira regional para o fomento de mecanismos de financiamento de longo prazo nas economias do Mercosul, assim como para o enfrentamento da fragilidade externa desses sistemas. Com esse intuito, o artigo foi organizado em duas seções. Na seção 1, procurou-se discutir os sistemas financeiros dos países-membros do Mercosul, com olhar especial sobre a existência de mecanismos de financiamento de longo prazo. $\mathrm{Na}$ seção 2 , avaliou-se a importância das instituições financeiras regionais no enfrentamento da questóes do financiamento do investimento e de manejo da liquidez externa.

\section{2_As assimetrias nos sistemas financeiros do Mercosul e a questão do financiamento de longo prazo}

Os sistemas financeiros dos países que compóem o Mercosul apresentam diversidade de estrutura no que diz respeito a tamanho, profundidade, complexidade e nível de abertura externa. Isso reflete, ao mesmo tempo, a institucionalidade vigente em cada um dos sistemas e a heterogeneidade das economias em questão. ${ }^{4}$

\footnotetext{
Em Studart e Herrman (2001), Paula e Alves Jr. (2007) e Carvalho et al. (2010) encontram-se informaçóes e análises abrangentes sobre a institucionalidade vigente nos sistemas financeiros em questão.
} 
No entanto, há algumas características comuns que merecem ser destacadas.

Em primeiro lugar, e articulado com a implementação de um novo regime macroeconômico, centrado na rigidez cambial, e do novo perfil de inserção externa (maior abertura), deve-se apontar que houve forte movimento de liberalização financeira, na década de 1990, em todas as economias do bloco. Em maior ou menor grau, foram tomadas medidas para diminuir as restrições ao movimento de capitais, de modo a atraí-los. No mesmo sentido, estimulou-se a entrada de instituições estrangeiras nos sistemas bancários domésticos. ${ }^{5}$ Deve-se salientar, contudo, que esse movimento de liberalização financeira não foi acompanhado de maior integração financeira regional, seja no âmbito do Mercosul, seja mesmo no de outros países da América do Sul.
Ademais, como apontam Amado e Silva (2000), diante de situaçóes de assimetrias estruturais e da falta de coordenação dos Estados, maiores níveis de abertura tendem a reforçar as diferenças existentes, ao invés de reduzi-las.

Um segundo aspecto importante, que manifesta os nexos entre a dimensão macro e a estrutura dos sistemas financeiros, é terem as quatro economias experimentado crises severas nas décadas de 1990 e 2000, advindas do setor externo, e que todas essas, com exceção do caso brasileiro, transformaram-se em crises bancárias. ${ }^{6}$ Vale observar mais de perto alguns aspectos de cada um dos sistemas, com ênfase especial nos casos de Brasil e Argentina.

O sistema financeiro brasileiro passou por mudanças importantes nos anos 1990. Entre essas transformaçóes, destacam-se: (i) o processo de liberalização fi-

\footnotetext{
${ }^{5}$ Vale dizer que esses sistemas financeiros são caracterizados pela presença de bancos, isto é, que as economias do Mercosul são economias de crédito, e não de mercados de capitais. A título de exemplo, podemos apontar que, na Argentina, em 2007, as instituiçóes bancárias detinham cerca de 98\% dos ativos e dos passivos do sistema.
}

\author{
${ }^{6}$ No caso do Brasil, é \\ possível afirmar que, se não \\ houve crise bancária aberta, \\ como nos outros países, \\ certamente houve grande \\ fragilização do sistema na \\ segunda metade dos anos \\ 1990, majoritariamente \\ influenciada por fatores \\ internos - a redução da alta \\ inflação -, mas agravada
}

\author{
pela execução de políticas \\ macroeconômicas voltadas \\ para a manutenção da \\ inserção externa. Diante dessa \\ situação, o Banco Central do \\ Brasil adotou um conjunto de \\ medidas emergenciais para \\ garantir o saneamento do \\ sistema. Ademais, autoridades \\ governamentais garantiram, \\ em vários momentos,
}

\author{
proteção cambial e de taxa de \\ proteçáo cambial e de taxa de \\ juros, por meio da emissão \\ de títulos públicos atrelados \\ ao dólar e à taxa over-selic. \\ Tal postura facilitou o \\ enfrentamento dos choques \\ externos vivenciados no \\ período 1997-2002 e garantiu \\ aos bancos a combinação de \\ solidez e rentabilidade (Paula; \\ Alves Jr., 2007).
}


nanceira, que possibilitou a entrada de capitais estrangeiros no sistema; (ii) a perda do importante lucro inflacionário após o Plano Real, que impactou fortemente as instituiçóes financeiras; (iii) um amplo movimento de fusóes e aquisiçóes, associado a processos de intervenção e liquidação de bancos privados e extinção ou privatização de grande parte dos bancos públicos estaduais, o que implicou uma importante diminuição do segmento público no sistema financeiro, concomitante a um aumento da participação estrangeira no referido setor; (iv) reestruturação das instituições financeiras públicas federais.

Vale notar que esse sistema é composto de abrangente gama e um grande número de instituiçôes bancárias e não bancárias. Contudo, são as instituições bancárias as responsáveis pela quase totalidade dos ativos, cabendo às instituições não bancárias menos de $1 \%$ desses. No que tange aos bancos, em junho de 2008 havia 136 bancos múltiplos, 20 bancos comerciais e uma Caixa Econômica. ${ }^{7}$ Entre os bancos, os comerciais e os múltiplos com carteira comercial detinham, em 2008, cerca de $85 \%$ dos ativos do sistema (BCB, 2008). A decomposição dos ativos e dos passivos bancários por origem de capital explicita a importância dos bancos de capital nacional, públicos ou privados, responsáveis por cer- ca de $80 \%$ do sistema ${ }^{8}$. Destaque deve ser dado à participação dos bancos públicos nas operações de crédito: $34,1 \%$ em junho de $2008^{9}$ (BCB, 2008).

A análise da composição do crédito em dezembro de 2008 por segmento de destino e origem de capital descortina alguns dos elementos presentes no sistema brasileiro (BCB, 2009). Em primeiro lugar, aponta que o setor privado é receptor da maioria dos recursos emprestados $(97,8 \%)$, cabendo pequena parcela desses ao setor público, majoritariamente ofertado pelos bancos públi$\cos ^{10}{ }^{10}$ Em segundo lugar, evidencia que os bancos públicos têm atuação diferenciada nos segmentos habitacional e rural, dado que eles ofertam $71 \%$ e $57 \%$, respectivamente, do crédito para tais setores. Essa dimensão do papel dos bancos públicos reflete a atuação de duas insti-

${ }^{7}$ Contudo, a despeito do
grande número de instituiçóes,
o sistema é bastante
concentrado.
${ }^{8}$ Observa-se a presença, ainda
que irrelevante no total de
ativos bancários, de filiais
de dois bancos argentinos
e um uruguaio, de capital
público, no sistema (Banco
de la Provincia de Buenos
Aires - 0,004\% dos ativos;
Banco de la Nación Argentina
- 0,003\% dos ativos; e Banco
de la Republica Oriental de Uruguay - 0,001\% dos ativos).

${ }^{9}$ Inclui os bancos públicos comerciais, múltiplos e a Caixa, e exclui o BNDES.

${ }^{10}$ Cabe lembrar que há restrições legais ao endividamento do setor público, assim como limitaçóes colocadas pela regulamentação bancária à capacidade de empréstimos das instituições a esse. 
${ }^{11} \mathrm{E} 17,1 \%$ com recursos totais - direcionados e livres (BCB, 2009). tuições federais, quais sejam, Caixa Econômica Federal (CEF) e Banco do Brasil. Em terceiro lugar, permite observar a maior participação relativa das operaçóes para pessoas físicas (32\% do total das operaçóes de crédito), seguida dos setores industrial e de outros serviços. Por fim, observa-se que a atuação dos bancos estrangeiros no mercado de crédito é mais limitada (detêm 21\% desse mercado).

Uma peculiaridade do sistema financeiro brasileiro, de particular interesse para a discussão ora apresentada, diz respeito à presença de mecanismos de direcionamento de crédito, originados com base no diagnóstico de que alguns segmentos/regiōes da economia merecem tratamento diferenciado. O direcionamento de crédito no Brasil se dá basicamente de duas formas. A primeira impóe a vinculação entre instrumentos de captação e aplicação de recursos. É esse o caso do direcionamento para crédito imobiliário, bem como para empréstimos rurais e microcrédito. $\mathrm{O}$ segundo processo de direcionamento parte da existência de grandes fundos fiscais e parafiscais, tais como Fundo de Amparo ao Trabalhador (FAT), Fundo de Garantia do Tempo de Serviço (FGTS) e Fundos Constitucionais (FCO, FNO, FNE). Esses fundos servem como instrumento fundamental de funding para segmentos e regióes especí- ficos da economia brasileira, tais como: (i) financiamentos de longo prazo fornecidos pelo Banco Nacional de Desenvolvimento Econômico e Social (BNDES) a partir dos recursos do FAT; (ii) financiamentos concedidos majoritária, mas não exclusivamente, pela CEF, com funding do FGTS à habitação, ao saneamento e à infraestrutura urbana; (iii) financiamentos destinados a regióes específicas, tendo em vista os recursos dos Fundos Constitucionais. Cabe destacar que o uso de tais recursos ocupa papel fundamental no financiamento dos segmentos listados, com desdobramentos importantes para a própria dinâmica de funcionamento da economia brasileira.

No total do estoque de crédito direcionado, o crédito ofertado pelo BNDES, com base em recursos do FAT, assume papel preponderante, tendo representado, no final de 2008, 58,8\% das operaçóes de crédito com recursos direcionados ${ }^{11}(\mathrm{BCB}$, 2009). Destaque deve ser dado também à atuação da CEF no fornecimento dos recursos de longo prazo para pessoas físicas - caso das operaçóes de crédito habitacional - com funding no FGTS e no sistema de poupança e empréstimo (depósitos de poupança). A importância dessas instituiçôes no fornecimento de recursos de longo prazo fica ainda mais clara quando se avalia a estrutura de vencimentos das 
operaçóes de crédito no Brasil e se observa a grande concentração em operaçóes de prazos mais curtos $-54,7 \%$ para pessoas físicas e $55,5 \%$ para pessoas jurídicas em 2008 (BCB, 2009).

Enfim, chama a atenção no sistema financeiro brasileiro o papel preponderante do sistema bancário, com grande concentração de ativos e passivos nos bancos múltiplos. Dentro desse sistema, e a despeito do aumento da participação do capital estrangeiro na década de 1990, observa-se papel ainda importante do capital doméstico, público e privado. Vale destacar a relevância dos bancos públicos (26,7\% dos ativos do sistema em junho de 2008), ${ }^{12}$ resultado de presença expressiva e histórica no sistema, e não de um processo de enxugamento do setor privado nos ajustes pós-crise, como observado nos sis- temas argentino e uruguaio (BCB, 2008). Relacionado a esse sistema de bancos públicos e implementado por estes - em especial BNDES, mas também CEF -, está um importante sistema de financiamento de longo prazo, fortemente calcado na já destacada presença de grandes fundos de poupança compulsória. O BNDES tem como fonte importante de funding o Fundo de Amparo ao Trabalhador (FAT), ao passo que a CEF é a principal instituição a utilizar recursos do Fundo de Garantia do Tempo de Serviço (FGTS). ${ }^{13}$

Mais recentemente - após 2003 -, destaca-se a expansão dos mercados de crédito e de capitais no Brasil. ${ }^{14} \mathrm{O}$ saldo das operaçôes de crédito quase duplicou entre 2002 e 2008, quando atingiu o volume recorde de $41,1 \%$ do PIB $^{15}$ (BCB, 2009). Esse crescimento deve ser enten-
${ }^{12}$ Inclui os ativos dos bancos públicos comerciais, múltiplos e Caixa. Não estáo incluidos os ativos do BNDES.

${ }^{13}$ Como já destacado, o Brasil possui um robusto sistema de crédito direcionado, marcado pela presença de grandes fundos fiscais e parafiscais, além de relações de direcionamento de instrumentos de captação para certas modalidades de crédito. Os bancos públicos federais ocupam papel central nesse sistema, seja por deterem o monopólio do uso dos recursos - como é o caso do uso do FAT, pelo BNDES, ou dos fundos constitucionais, pelo Banco do Brasil, Banco do Nordeste e Banco da Amazônia - seja por estratégia - como no caso da CEF para o financiamento habitacional e de saneamento público por meio dos recursos do FGTS. Uma discussão aprofundada dos mecanismos de direcionamento é encontrada em Prates e Biancareli (2009) e Mendonça (2009).

${ }^{14} \mathrm{O}$ mercado de capitais experimentou crescimento em um período mais limitado, em especial de 2006 e 2007.

${ }^{15}$ Vale notar que alguns dos indicadores utilizados referemse ao PIB, notadamente os calculados pelo $\mathrm{BCB}$, enquanto outros se relacionam ao PNB, em especial aqueles fornecidos pelo Financial Structure Database, do Banco Mundial. Estes últimos são extremamente relevantes para o trabalho, uma vez que possibilitam a comparação entre os países em questão. Acredita-se que essa seja uma questáo metodológica que em nada interfere na qualidade da análise das informaçôes, em especial porque as comparaçóes só são realizadas entre indicadores de mesma base. 
dido por meio da combinação de fatores conjunturais - como o movimento tendencial de queda das taxas de juros e o crescimento da economia - e mudanças institucionais. Entre essas, destacam-se a criação do crédito consignado, a normatização da securitização de recebíveis e o estímulo ao mercado de debêntures.

Também se deve observar que o mercado de títulos de dívida privada é ainda pequeno, mas passou por transformações na primeira metade dos anos 2000, chegando a ocupar, nos anos de auge, papel importante, quando comparado com períodos anteriores, na captação de recursos de longo prazo. ${ }^{16}$

Cabe ressaltar o maior nível de internacionalização de grandes bancos brasileiros quando comparados com seus congêneres argentinos, paraguaios e uruguaios, evidenciada também por sua pre- sença em alguns ou na totalidade dos países do bloco Mercosul. Destaque deve ser dado ao Itaú Unibanco, atuante nos três sistemas. ${ }^{17}$ No entanto, é importante explicitar que o total de ativos mantidos por esses bancos no exterior é muito reduzido quando comparado com os ativos no Brasil e que, mesmo quando se consideram somente os ativos mantidos por tais instituições no exterior, os países do Mercosul são pouco representativos do total de ativos das instituiçóes brasileiras. ${ }^{18}$ Isto é, os bancos brasileiros são pouco internacionalizados, e, no âmbito dessa tímida internacionalização, o Mercosul não tem papel de destaque.

O sistema financeiro argentino sofreu amplo processo de liberalização no início dos anos 1990, que o tornou mais aberto e integrado internacionalmente, fortemente marcado por posiçóes ativas
${ }^{16} \mathrm{O}$ quadriênio 2005-08 foi marcado por intenso processo de emissão de debêntures, totalizando cerca de US $\$ 93,3$ bilhôes (www.debentures. com.br). Paula et al (2009), ao analisarem o mercado de títulos da dívida privada no período 2004-2008, sua evolução e seus determinantes, apontam o mesmo movimento de emissão de debêntures no período, com destaque para o ano de 2006.

\footnotetext{
${ }_{17}$ Mesmo antes da fusáo com o Unibanco, ocorrida em fevereiro de 2009, que criou o Itaú Unibanco, o Itaú já era o mais internacionalizado dos bancos brasileiros. Nos anos 1990, esse banco promoveu um processo de expansão no mercado argentino. Ademais, ampliou sua posição na regiáo (em especial no Chile e no Uruguai) por meio da compra do BankBoston, em 2006, e da aquisiçáo da carteira do
}
ABN Amro em Montevidéu, no início de 2007.
${ }^{18}$ No caso do Itaú, o banco brasileiro com maior participação nos países do Mercosul, o ativo e o patrimônio líquido correspondentes à presença dessas instituiçôes nos países

\author{
Argentina era responsável por \\ 4,4\%, o Itaú Uruguai por 5,5\%, \\ e o Interbanco (subsidiária \\ no Paraguai) por 3,2\%. A \\ importância da Argentina nos \\ ativos e no patrimônio líquido \\ do Bradesco no exterior é \\ ainda menos importante, \\ ficando abaixo de $1 \%$.
} do Mercosul representavam, em março de 2009, 13,2\% e $7,8 \%$ do total das contas consolidadas no exterior. Desse total de ativos, o Itaú 
e passivas dolarizadas. ${ }^{19}$ Após um processo de fragilização crescente, esse sistema enfrentou, em 2001, uma crise de grandes proporçóes que refletiu, sobretudo, o arranjo macroeconômico do país e sua profunda abertura ao sistema financeiro internacional. Nessa crise, 51 instituições faliram e observou-se movimento intenso de fusão e aquisição.

Cabe ressaltar que a crise ocasionou importante encolhimento do sistema, o que se expressou, por exemplo, na redução no volume de crédito, principalmente ao setor privado, no período de 1999 a 2003. A relação crédito/PNB, que estava em torno de $25 \%$ em 1999 , caiu a partir de então e até 2003, quando se estabilizou em percentual levemente inferior a 10\% (World Bank, 2007).

Em 2004, no contexto de crescimento - retomado em 2003 - e com a reorganização das operaçôes bancárias, houve retomada das operações de crédito e do volume de depósitos. Os bancos, em especial os públicos, voltaram a emprestar. Apesar desse movimento, as operações de crédito em relação ao PNB representavam, em 2007, 50\% do observado em 1999 (12,51\% ante 25,18\%).

Outra característica explicitada no período posterior à crise foi a "desdolarização" das operaçóes, que ocorreu de forma pronunciada a partir de 2002. Isso se ob- servou tanto no que diz respeito aos passivos, como no que concerne à carteira de crédito. A captação em moeda doméstica passou de 22,9\% em 2001 para 68,1\% em 2008. As operaçóes de crédito em moeda estrangeira, que representavam $77,9 \%$ do total em 2001, passaram a 12,9\% em 2008.

A composição dos ativos e dos passivos bancários por tipo de instituição e origem de capital no ano de 2007 evidencia algumas características do sistema financeiro argentino. Primeiro, apontou a preponderância das instituiçóes bancárias, que detinham 98\% dos ativos e dos passivos do sistema. Segundo, revelou que os bancos públicos eram responsáveis por cerca de $40 \%$ dos ativos e dos passivos do sistema e por $29 \%$ do total de empréstimos. Já os bancos privados, que detinham $59 \%$ dos ativos do sistema, eram responsáveis por $68 \%$ dos empréstimos. Em terceiro lugar, mostrou que, entre as instituiçóes privadas, havia participação bastante equilibrada de bancos de capital nacional (31,6\% dos ativos, $36,1 \%$ dos empréstimos ao setor privado e $32,2 \%$ dos depósitos do setor privado) e de capital estrangeiro $(27,4 \%$ dos ativos, $35,1 \%$ dos empréstimos ao setor privado e $36,4 \%$ dos depósitos do setor privado). Entre os bancos de capital estrangeiro, observa-se a presença de instituições de capital brasileiro, a despei-
${ }^{19}$ As operaçōes de crédito em moeda estrangeira representavam $77,91 \%$ do total das operaçóes em 2001. 
${ }^{20}$ Dados de março de 2009.

${ }^{21}$ Desde fevereiro de 2009, passou a ser Itaú Unibanco, maior banco privado brasileiro. to de essas não ocuparem papel de maior importância no sistema. Deve-se observar a presença de bancos brasileiros: Bancos Itaú (Itaú S.A., 16a instituição em ativos, $1,2 \%$ do total de ativos), Bradesco ( $71^{\mathrm{a}}$ instituição em ativos, $0,04 \%$ do total de ativos) e Banco do Brasil (76a instituição em ativos, $0,03 \%$ do total de ativos). ${ }^{20} \mathrm{O}$ Banco de la Nación Argentina, por sua vez, a despeito da ínfima participação, está presente nos sistemas financeiros de Brasil, Paraguai e Uruguai.

Por último, deve-se salientar a inexistência de instrumentos de financiamento de longo prazo no mercado bancário argentino. Mesmo o movimento recente do mercado de capitais aponta a preponderância de emissão de prazo mais curto, tais como os títulos públicos e os fideicomissos.

A atual estrutura do sistema financeiro paraguaio resulta de sua história recente, marcada por um processo de liberalização ocorrido na década de 1990 e de crises financeiras que se seguiram. Vale destacar que essas foram resultado não só de fragilidade inerente ao sistema, mas, em especial, representaram desdobramentos das crises ocorridas no sistema financeiro argentino.

Em 2008, o sistema bancário do Paraguai era formado por seis sucursais de bancos estrangeiros, cinco bancos de capi- tal majoritariamente estrangeiro, dois bancos privados de capital majoritariamente doméstico e um banco público. A participação dos bancos privados era dominante e representava 96,7\% dos empréstimos. Entre os bancos privados, os estrangeiros - sucursais ou de capital majoritário estrangeiro - detinham por volta de $65 \%$ dos ativos, depósitos e operações de crédito do sistema (BCP, 2008, 2009). Cabe destacar que, entre as sucursais de bancos estrangeiros, figuram um banco brasileiro e um argentino, ambos com capital de origem pública, integral ou majoritariamente. O Banco do Brasil, em 2008, com uma única agência, ocupava a décima posição - com 3,55\% dos ativos e 4,33\% dos empréstimos, notadamente para o setor financeiro. O Banco de la Nación Argentina, por sua vez, ocupava o décimo quarto lugar em ativos e era responsável por $1,43 \%$ desses e $1,10 \%$ dos empréstimos, notadamente voltados para o financiamento de exportaçôes. Já entre os bancos com capital majoritário estrangeiro, destaca-se a participação de um grande banco privado brasileiro, Unibanco, ${ }^{21}$ proprietário do Interbanco S.A., maior banco atuante no Paraguai, responsável por $14,50 \%$ dos ativos do sistema bancário, em dezembro de 2008.

Deve-se apontar que o sistema financeiro paraguaio é pequeno absoluta e 
relativamente. Tal sistema é marcado pela presença significativa de bancos, ${ }^{22}$ que detinham $75 \%$ do total dos depósitos e $62 \%$ do total dos créditos do sistema financeiro em 2006 (BCP, 2007, 2008). O volume de ativos do sistema bancário em 2008 era da ordem de US\$ 4,4 bilhóes. A relação crédito/PNB, por sua vez, que chegou ao pico de $29 \%$ em meados dos anos 1990 , teve queda importante, atingindo $18,2 \% \mathrm{em}$ 2007 (World Bank, 2008; BCP, 2008). Vale destacar que não se observa a presença de instrumentos de financiamento de longo prazo no mercado bancário.

O sistema financeiro uruguaio passou por intenso processo de liberalização no início dos anos 1990, que resultou em um sistema mais aberto e integrado internacionalmente e fortemente marcado por posições ativas e passivas dolarizadas. Na verdade, a institucionalidade do sistema permite a implementação de operações de mercado off-shore, havendo instituições financeiras que têm atuação restrita às operaçôes com não residentes.

Esse sistema enfrentou uma crise de grandes proporçóes no início dos anos 2000, resultado não só da própria fragilidade e de sua institucionalidade, mas também e em especial como desdobramento das crises do sistema financeiro argentino. ${ }^{23} \mathrm{~A}$ conjunção de problemas de liquidez gerados pela forte retirada de depósi- tos e pelo crescimento dos empréstimos problemáticos após a desvalorização cambial, além de problemas de governança, levou à quebra de vários bancos (FMI, 2006). Nesse contexto, quatro grandes bancos foram fechados e cerca de um terço das instituições financeiras deixou de existir. Diferentemente do observado em outras crises, os bancos que quebraram foram liquidados. Tal processo gerou uma característica ímpar desse sistema financeiro relativamente ao dos outros países do bloco: a quase inexistência de bancos privados nacionais. Assim sendo, cresceu a participação dos bancos públicos e estrangeiros em um sistema que encolheu violentamente.

O sistema financeiro uruguaio era e continuou sendo, após a crise, pequeno em termos absolutos, quando comparado com os sistemas brasileiro e argentino. No entanto, era um sistema relativamente importante, antes do processo de encolhimento gerado pela crise. Como enunciado acima, a crise ocasionou forte enxugamento do sistema, tanto no que diz respeito aos recursos captados quanto no que concerne aos recursos emprestados. A relação operaçóes de crédito sobre o PNB tem se apresentado como a mais baixa em décadas. Se no início dos anos 2000 o Uruguai apresentava o maior sistema financeiro em termos relativos en-
${ }^{22}$ Cabe destacar que, a despeito da participação preponderante do sistema bancário, o sistema não bancário no Paraguai empresas financeiras e principalmente cooperativas - detém posição mais importante do que aquela observada em outros países do bloco, como Argentina e Brasil.

${ }^{23}$ Ao final de 2001, os depósitos de não residentes representavam mais de $50 \%$ do total do sistema, e, quando da crise, a queda de depósitos totais foi de quase $50 \%$. Essa informação aponta a extrema fragilidade do sistema. 
tre os países do Mercosul, a situação em 2007 era bastante diversa, uma vez que os sistemas de outros países cresceram, ao passo que o uruguaio encolheu. Os depósitos, que atingiam quase $60 \%$ do produto em 2002, chegaram a 23\% em 2007 (BCU, 2008).

Vale apontar que o mercado de capitais é inexpressivo, e as instituições bancárias, sobretudo públicas e estrangeiras, dominam o sistema. A análise dos prazos das operaçóes de crédito concedidas pelos bancos, por sua vez, evidencia a presença de mecanismos de financiamento de longo prazo nesse sistema. Em 2008, o volume das operaçóes de crédito com prazo superior a um ano era de $42,8 \%$, e de $34,1 \%$, para operaçóes com prazo superior a três anos.

No que tange à existência de capital das outras economias do bloco no sistema financeiro uruguaio, deve-se apontar a presença de um grande banco privado brasileiro, qual seja, Itaú, responsável por 6,6\% dos ativos bancários, e do maior banco público argentino, Banco de la Nación Argentina, responsável por menos de $1 \%$ dos ativos bancários.

$\mathrm{O}$ intuito da presente seção foi apresentar a estrutura dos sistemas financeiros dos países do Mercosul. Atenção especial foi dada à indicação de existência de mecanismos de financiamento de longo prazo e de interpenetração de capital regional na propriedade das instituiçóes que compóem os referidos sistemas. A análise mostrou que, comparativamente, o sistema financeiro brasileiro é mais complexo e maior, não só em termos absolutos, mas também em termos relativos, que os sistemas argentino, uruguaio e paraguaio. Dentro do sistema brasileiro, e a despeito do aumento da participação do capital estrangeiro na década de 1990 , observa-se papel bastante importante do capital doméstico, público e privado. Vale destacar a relevância dos bancos públicos, com presença expressiva e histórica no sistema, que não resulta de um processo de enxugamento do setor privado nos ajustes pós-crise, como observado nos sistemas argentino e uruguaio. Relacionado a esse sistema de bancos públicos e implementado por estes - em especial BNDES, mas também Caixa Econômica Federal -, está um importante sistema de financiamento de longo prazo, fortemente calcado na presença de grandes fundos de poupança compulsória.

No que diz respeito à interpenetração de capital nos sistemas financeiros em âmbito regional, constatou-se a presença de bancos públicos da Argentina e do Uruguai no sistema brasileiro, ainda que numa proporção irrelevante (relativamente ao total de ativos desse sistema). 
Por outro lado, observou-se maior nível de internacionalização dos três maiores bancos brasileiros quando comparados com seus congêneres argentinos, paraguaios e uruguaios. No entanto, mesmo se considerados somente os ativos dessas instituições no exterior, a importância relativa dos países do Mercosul é baixa.

A tabela abaixo sintetiza essas informações. No que diz respeito ao Mercosul, as dificuldades dos sistemas financeiros desses países em engendrar financiamen- to de longo prazo reforçam o papel de instituiçóes financeiras regionais orientadas ao financiamento de longo prazo. Amado e Silva (2000) destacam que, para o avanço do processo integracionista, seria fundamental que os Estados nacionais criassem instituiçóes e mecanismos financeiros capazes de impulsionar o crescimento articulado entre as economias-parte. É nesse sentido que a próxima seção é organizada.

Tabela 1_Variáveis selecionadas dos sistemas financeiros argentino, brasileiro, paraguaio e uruguaio (2008)

\begin{tabular}{|c|c|c|c|c|}
\hline & Argentina & Brasil & Paraguai & Uruguai \\
\hline Crédito bancário/PNB & $13,4 \%$ & $46,0 \%$ & $18,2 \%$ & $22,6 \%$ \\
\hline Depósitos/PNB & $20,1 \%$ & $60,7 \%$ & $17,4 \%$ & $33,9 \%$ \\
\hline Concentração bancária & $41,2 \%$ & $83,2 \%$ & $47,0 \%$ & $79,4 \%$ \\
\hline Capitalização do mercado acionário/PNB & $30,4 \%$ & $113,3 \%$ & nd & $0,7 \%$ \\
\hline Valores negociados mercado acionário/PNB & $4,8 \%$ & nd & nd & nd \\
\hline Títulos públicos/PNB & $20,5 \%$ & $48,6 \%$ & nd & nd \\
\hline Dívida externa/PNB & $20,2 \%$ & $7,5 \%$ & nd & $42,1 \%$ \\
\hline Depósitos off-shore/Depósitos totais & $40,9 \%$ & $2,3 \%$ & $37,7 \%$ & $87,6 \%$ \\
\hline Ativos dos bancos estrangeiros/Total dos ativos bancários & $22,7 \%^{1}$ & $19,5 \%^{2}$ & $64,8 \%$ & nd \\
\hline Ativos dos bancos públicos/Total dos ativos bancários & $40,1 \%{ }^{1}$ & $26,7 \% \%^{2}$ & $7,2 \%$ & $43,6 \% \%^{3}$ \\
\hline \multicolumn{5}{|l|}{ Fonte: World Bank, 2008; BCRA (2007); BCB (2008), BCP (2007) e BCU (2008). } \\
\hline Dados de junho de 2008. & & & & \\
\hline
\end{tabular}




\section{3_A relevância da cooperação financeira regional para 0 financiamento do investimento e do fortalecimento da regionalização}

A análise precedente expôs a diversidade $e$ as assimetrias entre os sistemas financeiros dos países do Mercosul. Essas se expressam em termos de tamanho, profundidade, concentração, nível de abertura externa, importância do mercado de capitais e presença de mecanismos para financiamento de longo prazo. Neste último quesito, mas não apenas, o Brasil destaca-se relativamente aos demais sistemas, dada a presença de um sistema público de financiamento no qual o BNDES tem papel proeminente, como financiador dos investimentos, e de um mercado de capitais organizado, mesmo que em pequena escala. Vale destacar que o processo de liberalizaçấo financeira, por sua vez, não impulsionou a criação ou o aprofundamento de instrumentos para o financiamento de longo prazo.

Nesse sentido, a construção e o fortalecimento de mecanismos financeiros regionais têm sido colocados como alternativa para aprofundar sistemas financeiros de economias periféricas, bem como complementar a atuaçáo de instituiçóes financeiras internacionais, em casos de crise de balanço de pagamentos (Ocam- po, 2006; Culpeper, 2006; Agosin, 2001; Fanelli, 2008; Aboal et al., 2008). Tais iniciativas são especialmente importantes em um contexto de hierarquia de moedas em âmbito internacional e no qual se acentuam as assimetrias, nos processos de ajustamento externo, entre países devedores e credores (Prates; Cintra, 2008).

Neste trabalho, tomando como referência Fanelli (2008) e Ocampo (2006), as iniciativas de cooperação financeira regional serão analisadas em duas dimensōes. Na primeira, estáo aquelas cujo objetivo predominante é otimizar o manejo da liquidez externa - Convênio de Pagamentos e Créditos Recíprocos (CCR), Sistema de Pagamentos em Moeda Local (SML) e Fundo Latino Americano de Reservas (FLAR). Na segunda, estão as iniciativas voltadas, principalmente, para melhorar as condiçóes de acesso ao financiamento de longo prazo - Fundo para a Convergência Estrutural e Fortalecimento da Estrutura Institucional do Mercosul (Focem), Fundo Financeiro para o Desenvolvimento dos Países da Bacia do Prata (Fonplata) e a Corporaçáo Andina de Fomento (CAF).

É importante ressaltar que, dentro dos propósitos deste trabalho, a concepçáo de cooperação financeira regional faz sentido tendo-se em conta que essas instituiçóes estáo relacionadas com o aprofundamento da regionalização sul-ameri- 
cana. Assim, Focem e SML estão atrelados ao funcionamento do Mercosul; CAF, ${ }^{24}$ à Comunidade Andina de Naçóes (CAN); CCR, à Aladi (Associação Latino-Americana de Integração); Banco do Sul, à Uniáo Sul-Americana de Naçóes (Unasul). Já o Fonplata é vinculado aos cinco países que compóem a Bacia do Prata, ou seja, os países-membros do Mercosul e a Bolívia (Culpeper, 2006; Biancareli, 2008).

\subsection{Cooperação financeira regional: instituições voltadas para \\ o manejo da liquidez externa}

Os fundos regionais de reserva e os acordos para compensação de transaçóes de comércio exterior podem ser entendidos como uma "primeira linha de defesa" contra as crises financeiras internacionais que repercutem sobre a periferia, minimizando seus impactos sobre o comércio, as reservas e sobre o nível de atividade dessas economias. Para Ocampo (2006, p. 17):

"Em um mundo em que a margem de manobra das politicas macroeconômicas nacionais se reduziu, o âmbito regional passou a ser fundamental para o exercício da autonomia em matéria de política econômica que ainda existe".

É sob essa perspectiva que são apresentadas instituiçóes financeiras regionais como CCR, SML e FLAR.
O Convênio de Pagamentos e Créditos Recíprocos (CCR) foi originalmente criado em 1965, na esfera da Associação Latino-Americana de Livre Comércio (Alalc), sob a denominaçáo de Acordo de Pagamentos e Créditos Recíprocos. Foi ratificado quando a Alalc foi substituída, em 1980, pela Associação Latino-Americana de Integração (Aladi), mas, a partir de 1982, após alguns ajustes, passou a denominar-se Convênio de Pagamentos e Créditos Recíprocos (CCR). Integram-no 12 países: Argentina, Bolívia, Brasil, Chile, Colômbia, Equador, México, Paraguai, Peru, Uruguai, Venezuela e República Dominicana. ${ }^{25}$ Seus objetivos são estimular as relações financeiras entre os países e as instituiçóes financeiras da região, facilitar a expansão do comércio recíproco e reduzir os fluxos internacionais de divisas.

A partir de 1995, quando o convênio atingiu seu auge, as operaçóes cursadas pelo CCR no total do comércio regional diminuíram: sua participação foi de 1,6\% em 2003, contra os $84 \%$, em média, dos anos 1980. Levaram a essa redução o fim da obrigatoriedade de se cursar as operaçóes comerciais pelo CCR, bem como as restriçôes impostas pelos bancos centrais às operaçôes cursadas nesse convênio, dado o maior acesso dos países da região à liquidez internacional (Santana; Kasahara, 2006).

\footnotetext{
${ }^{24}$ Nota-se que, desde a modificaçáo do seu Convenio Constitutivo (2007), os países do Mercosul se tornaram membros, com participação acionária, portanto.
${ }^{25}$ São os países-membros da Aladi - com exceçáo de Cuba - mais a República Dominicana.


Contudo, a partir de 2003, houve recuperação no volume de operaçóes cursadas. A participação no total das importaçôes regionais apresentou tendência de crescimento desde então, tendo alcançado o volume de US\$12,66 bilhóes em 2008, o equivalente a $8,9 \%$ do comércio intrarregional, ${ }^{26}$ e de US $\$ 7,06$ bilhóes em 2009 , o que representou $6,7 \%$ do total das importações intrarregionais. Também deve ser registrado que, de 2004 a 2008, a taxa de crescimento das operaçôes no âmbito do CCR foi superior à taxa de expansão do intercâmbio comercial entre os países (CCR, 2008). Entretanto, essa recuperação observada nos últimos cinco anos esteve fortemente relacionada ao comportamento da Venezuela - em 2008 , por exemplo, $71 \%$ das suas importaçóes se deram por meio do convênio -, e a excessiva dependência do compor-

\footnotetext{
${ }^{26}$ No caso do Brasil, o valor cursado das exportaçóes no CCR chegou a 14\% em 1992. Em 2002, correspondia a menos de $1 \%$. Essa redução da presença do Brasil nas operaçóes cursadas deve-se a mudanças na regulamentação do CCR pelo país.

${ }^{27}$ Isto é, o exportador brasileiro recebe em real, e o exportador argentino,
}

em peso. Por sua vez, o
importador brasileiro paga
argentino, em oeso. A taxa de
câmbio entre as duas moedas
é a taxa SML, pela qual são
convertidos os valores fixados
das operaçóes cursadas no
SML. São divulgadas duas
Taxas SML: uma Real/Peso -
pelo Banco Central do Brasil
- e outra Peso/Real - pelo
Banco Central da Argentina.

tamento de um único país é motivo de preocupação em relação ao dinamismo futuro do CCR. Em 2009, por exemplo, a queda no volume das operaçóes canalizadas é justificada pela menor participação da Venezuela (CCR, 2010). De toda forma, mesmo com essa tendência de crescimento, o volume de operaçóes canalizadas no convênio não recuperou seu máximo histórico, que se deu em 1995 , quando foram registrados aproximadamente U\$ 14 bilhôes em operações.

Em 2008, entrou em vigor o Sistema de Pagamentos em Moeda Local (SML) entre Brasil e Argentina, o qual consiste num sistema de pagamentos transfronteiriço integrado aos sistemas de pagamentos locais e destinado a operaçōes comerciais. Essa iniciativa se inscreve numa perspectiva semelhante à do CCR, qual seja, reduzir a necessidade de divisas no comércio regional de bens e serviços e, com isso, contribuir para incrementá-lo. Contudo, o SML não deve ser entendido como uma "versão mercosulina” do CCR. Na verdade, esse sistema de pagamentos é, em certo aspecto, mais ambicioso, uma vez que a liquidação das transaçóes para os importadores e os exportadores é feita em moeda local. ${ }^{27}$ Apenas a compensação entre os bancos centrais é feita em dólares. Portanto, como aponta Carvalho (2009), o SML não re- 
presenta a "desdolarização" do comércio, ainda que seja um passo nesse sentido e represente avanço importante na integração financeira da América do Sul. ${ }^{28}$

O objetivo do SML é possibilitar que importadores e exportadores reduzam seus custos e simplifiquem suas operaçóes, levando a uma ampliação do comércio internacional entre os países membros, sobretudo pela maior participação das micros, pequenas e médias empresas. Em outubro de 2008, primeiro mês de funcionamento do sistema, foram contabilizadas três operações de exportação brasileiras no âmbito do SML. Já em dezembro de 2008, foram registradas 18 dessas operaçōes; em dezembro de 2009, foram 168, e, em outubro de 2010, essas totalizaram 370 - tendência de crescimento da utilização do sistema pelos exportadores brasileiros. Como aponta Barreto (2009), a migração das empresas para o sistema é ainda marginal, mas crescente. No que diz respeito às importaçóes brasileiras $\mathrm{da}$ Argentina, o grau de intensidade de utilização do SML é muito inferior e não se pode inferir tendência de crescimento. $\mathrm{Na}$ Cúpula do Mercosul de julho de 2009, foi ratificada a entrada, para 2010, de Paraguai e Uruguai.

Por fim, cabe analisar o papel do Fundo Latino-Americano de Reservas (FLAR) no contexto de uma arquite- tura financeira internacional na qual se sobressaem as diferenças de poder monetário-financeiro e, por conseguinte, as assimetrias entre credores e devedores nos processos de ajustamento dos balanços de pagamentos. Assim, instituições financeiras regionais capazes de apoiar financeiramente os países periféricos no enfrentamento dos déficits advindos da sua condição estrutural são primordiais (Agosin, 2004). É esse o sentido da atuação do FLAR, criado em 1978, integrado por sete países - Bolívia, Colômbia, Costa Rica, Equador, Peru, Uruguai e Venezuela, sendo o Uruguai o único membro pleno do Mercosul - e que tem como maior objetivo financiar o balanço de pagamentos dos seus membros. ${ }^{29} \mathrm{O}$ volu-

\author{
Mercosul, bem como de \\ proteção das reservas cambiais. \\ ${ }^{29}$ Como ressaltam Agosin \\ e Heresi (2010), o FLAR \\ concede créditos para \\ financiar o balanço de \\ pagamentos de acordo com \\ a situação enfrentada - \\ desequilíbrios nos termos de \\ intercâmbio ou de volumes \\ exportados - cuja duraçáo \\ pode chegar a três anos; \\ concede provisôes de liquidez \\ cujo prazo é de um ano e \\ créditos de contingência.
}


me de capital aportado pelo país-membro é o critério para definir seu limite de crédito junto ao fundo. O capital do fundo em 2008 era de US\$ 410,6 milhões, e o volume total de ativos, de US\$ 452 milhóes.

Ao longo de seus 32 anos de atuação, o FLAR teve papel muito destacado no contexto das crises externas. Agosin e Heresi (2010) mostram que, desde a sua fundação, em 1978, até 2009, o FLAR desembolsou créditos no valor de US\$ 6,18 bilhōes, destinados principalmente à provisão de liquidez e ao apoio ao balanço de pagamentos de seus países-parte. De fato, os desembolsos desse fundo se elevam quando das crises. Foi o que ocorreu no período 1982-84, auge da crise da dívida na América Latina; em 1995, quando da crise russa, e em 1998-99, período da crise da Ásia, bem como na mais recente crise financeira global. ${ }^{30}$ Ademais, sendo o grau de condicionalidades exigidas menor que o do FMI, seus empréstimos são relativamente mais rápidos, e a ação, assim, mais efetiva. ${ }^{31}$ Contudo, dado o volume pouco expressivo de recursos que pode mobilizar, o apoio do FLAR é de fato importante sempre e quando a interrupção nos fluxos de capitais não for generalizada. Isto é, quando não se tratar de uma crise global, e sim de uma crise circunscrita e de menor duração. Assim, Biancareli (2008), Montoya (2007) e Agosin (2001) reiteram a relevância da ampliação do FLAR para outros países da região, já que seria uma instituição desse tipo que desempenharia o papel efetivo de "complementaridade e concorrência" ante o FMI. ${ }^{32}$ Além disso, relativamente ao FMI, alguns fatores tornam esse tipo de arranjo mais exitoso
${ }^{30}$ Agosin e Heresi (2010, p.21) demonstram que o volume de recursos desembolsados pelo fundo cresceu de forma significativa no período 1982 1991, com destaque para o ano de 1984. A propósito, foi esse o ano com o maior volume de desembolsos ao longo de toda a série (1978-2009), tendo sido a Colômbia o tomador mais importante no referido ano. De 1992 a 1994, náo houve concessão de crédito, movimento que foi revertido nos anos de 1995 e 1996 destaque para o Equador. Em 1997, novamente não há registro de concessão de crédito e em 1998 e 1999 , respectivamente, Equador e Colômbia tomam recursos de forma expressiva. Nos anos 2000, o destaque fica para os créditos outorgados no ano de 2009, na esteira da crise financeira internacional.
${ }^{31}$ Montoya (2007) lembra que, apesar da limitada capacidade financeira de seus sócios, isto é, do volume de recursos pequeno que esse fundo pode mobilizar, relativamente ao de instituiçóes como o Banco Mundial ou o BID, a maior rapidez de sua ação torna-se uma "vantagem comparativa".

${ }^{32}$ Machinea e Titelman (2007) apud Biancareli (2008) realizam algumas simulaçóes para evidenciar que um caminho interessante seria, de fato, incorporar outros países sul-americanos a esse fundo, uma vez que ele forneceria proteção ampliada contra crises financeiras. Por outro lado, Biancareli (2008) faz uma ressalva, tendo em vista a possível restrição legal que alguns deles - como Argentina e Brasil - apresentam quanto ao compartilhamento de reservas externas. 
quanto ao menor risco de moratória por parte de um país-membro: o endividamento de cada país é limitado, o custo da perda de reputação é elevado, e os países têm interesses econômicos e políticos comuns (Montoya, 2007).

\subsection{Cooperação financeira regional: a construção de mecanismos de financiamento de longo prazo}

Nos anos 1990, os acordos de integração regional e sub-regional foram construídos em um contexto de abertura multilateral das economias-parte. Mais especificamente, os acordos deveriam promover a liberalização dos mercados e ser formulados com critérios flexíveis para a participação dos países (Baumann, 2005). O Mercosul se insere, de fato, nessa perspectiva, na qual a ideia de uma redistribuição dos ganhos do processo de integração, tendo em vista as disparidades entre as economias, não foi contemplada ( $\mathrm{Fa}$ ria, 1993; Motta-Veiga; Rios, 2007).

Contudo, mais recentemente se reconheceu que as assimetrias - de caráter estrutural e relacionadas ao nível de desenvolvimento relativo e ao tamanho dos países do Mercosul - não permitiam que o próprio esquema de integração se consolidasse (Sáez, 2008). Foi nesse contexto que se deu a criação do Fundo de Convergência Estrutural do Mercosul (Focem), que está:
Destinado a financiar programas para promover a convergência estrutural; desenvolver a competitividade; promover a coesão social, em particular das economias menores e regióes menos desenvolvidas, e apoiar of funcionamento da estrutura institucional e o fortalecimento do processo de integração (MER-

COSUL/CMC/DEC No28/06).

O Fundo foi criado em 2004, estabelecido em junho de 2005, mas tornou-se operacional em 2007. O montante anual de contribuição dos membros ao Focem é de US\$ 100 milhóes. ${ }^{33} \mathrm{O}$ Brasil deve contribuir com 70\%; Argentina; com 27\%; Uruguai, com 2\%; e Paraguai, com $1 \%$ (porcentagens estabelecidas em função da participação histórica do PIB dos países no PIB total do bloco). Em termos de distribuição de recursos, Paraguai deve receber 48\%; Uruguai, 32\%; Argentina e Brasil, 10\%. Ressalta-se, assim, o caráter redistributivo do fundo, que deve privilegiar obras de infraestrutura destinadas a facilitar o processo de integração (MERCOSUL/CMC/DEC No28/06). ${ }^{34}$

No biênio 2007-2008, tiveram início, no âmbito do fundo, 25 projetos, cujo financiamento somou US\$ 138,7 milhóes. Quanto à dimensão, apesar de seu valor absoluto parecer pouco expressivo, vale apontar que, em termos relativos, os montantes disponibilizados pelo Focem não

\footnotetext{
${ }^{33}$ No primeiro ano orçamentário do fundo, os Estados deveriam integralizar $50 \%$ de suas contribuições anuais para a execução de projetos-piloto. No segundo ano, $75 \%$, e, a partir do terceiro ano, $100 \%$.

${ }^{34}$ Biancareli (2008) critica o reduzido foco que esse fundo dá ao processo de mudança estrutural, além de apontar para sua reduzida dimensão - em termos do volume de recursos que pode mobilizar.
} 
estão muito aquém daqueles disponibilizados pela União Europeia em seus fundos estruturais e de coesão ${ }^{35}$ (Souza et al., 2010). Ainda, para Souza et al. (2010), a orientação do fundo, para financiar projetos em quatro setores-chave - infraestrutura física, estrutura produtiva, coesão social e fortalecimento institucional do bloco -, evidencia uma preocupação acertada, uma vez que a redução das assimetrias nesses setores é fundamental para reduzir as assimetrias no bloco. Como no Mercosul o tamanho e o nível de desenvolvimento das economias-parte são muito díspares, é mister que um fundo voltado para reduzir assimetrias estruturais se destine a atender economias menores e regiōes menos desenvolvidas dos Estados-parte.

Portanto, o Focem é crucial para o aprofundamento do Mercosul. Além de financiar investimentos, faz isso de modo a amenizar progressivamente as diferenças estruturais. Essas, quando não são objeto de políticas ativas, tendem a ampliar as desigualdades entre os países do bloco (Mollo; Amado, 2001).

Outra instituição que atua nesse sentido é o Fundo Financeiro para o Desenvolvimento dos Países da Bacia do Prata (Fonplata). Criado em 1974, ${ }^{36}$ como resultado das negociaçóes entre os governos dos cinco países que compóem a Bacia do Prata, ${ }^{37}$ iniciadas em meados da década de 1960 e que resultaram na assinatura do Tratado da Bacia do Prata, em 1969. Esse tratado institucionalizou o sistema hidrográfico do Prata, de modo que seus integrantes firmaram compromisso em promover o desenvolvimento harmonioso e a integração física da $\mathrm{Ba}$ cia do Prata.

O Fonplata é integrado por cinco países (Argentina, Brasil, Paraguai, Uruguai e Bolívia), dos quais quatro deles pertencem ao bloco Mercosul, e o quinto, a Bolívia, é um membro associado. Sua
${ }_{35}$ Ao longo dos dois anos de existência do Focem, o montante de recursos recebidos pelo Paraguai desse fundo seria equivalente a $0,8 \%$ do PIB, ao passo que a Irlanda, no período de 1989-2006, teria recebido dos fundos da UE $1,6 \%$ do PIB.

\author{
${ }^{36}$ Foi subscrito durante a \\ VI Reunião de Chanceleres \\ dos países da Bacia do Prata, \\ celebrada em Buenos Aires, \\ em junho de 1974. A primeira \\ sede oficial do Fonplata foi \\ Sucre, Bolívia, mas mudou- \\ se para Santa Cruz de la \\ Sierra, também na Bolívia, \\ em dezembro de 2002. O \\ fundo também conta com \\ um escritório em Assunção \\ (Paraguai), desde 1989 \\ (Fonplata, 2008). \\ ${ }^{37}$ A Bacia do Prata \\ compreende as bacias dos Rios \\ Paraná, Paraguai, Uruguai \\ e da Prata, nos territórios \\ da Argentina, da Bolívia, do \\ Brasil, Paraguai e do Uruguai.
}


base de capital, de US\$ 410,6 milhóes em 2008, formou-se a partir da contribuição original dos países-membros e é o seu funding principal. Neste sentido, não se vislumbra crescimento importante para o fundo, haja vista que seu funding e, assim, sua capacidade de atuação só podem aumentar significativamente pela ampliação de capital, e marginalmente pela emissão de títulos de dívida no mercado e pela capitalização do retorno de suas operaçóes. Do total de capital pago, Brasil e Argentina contribuíram cada um com $33,3 \%$, e Bolívia, Paraguai e Uruguai, juntos, com os $33,3 \%$ restantes. ${ }^{38}$ Destaca-se também a atuação do Fonplata no âmbito dos seguintes esforços integradores regionais:Comitê Internacional Coordenador dos Países da Bacia do Prata (CIC); Comitê Intergovernamental da Hidrovia Paraguai-Paraná (CIH); Iniciativa para a Integração Regional Sul-Americana (IIRSA). Deve-se lembrar que a criaçáo do Fonplata se deu para apoiar financeiramente projetos de infraestrutura, especialmente em torno dos rios que banham os seus países-membros (Faria, 1993).

Em 2008, ao todo, foram desembolsados US\$ 35,24 milhóes - 18,55\% a mais do que os desembolsos em 2004 para cumprir com os compromissos de financiamento de seus projetos de infraestrutura assumidos junto aos países acio- nistas. Nota-se que a Argentina - país que, juntamente com o Brasil, mais contribui para o capital do fundo - absorveu a maior parcela de recursos desembolsados no triênio 2006-2008, (52,5\%, 53,1\% e $41,8 \%$, respectivamente), seguido pelo Brasil. Já em 2008, o Brasil teve a maior participação nos desembolsos (49,1\%), ficando a Argentina com o segundo posto $(41,8 \%)$. Nesse mesmo ano, o Fonplata destinou 5,8\% dos desembolsos para a Bolívia, e ao Paraguai, 2,8\%. Além de contemplar os países, o Fonplata provê desembolsos a Operaçóes de Cooperação Técnica específicas na área de infraestrutura dentro da IIRSA e dos comitês dos quais participa (CIC e CIH). Esses desembolsos, em 2008, foram 17,36\% menores do que em 2006.

A carteira de empréstimos por país também aponta tendência de crescimento, haja vista que, em 2007, os empréstimos foram de US\$230 milhôes - aumento de 18,55\% em relação a 2004. Mais uma vez, Brasil e Argentina foram os principais beneficiados pelos empréstimos do Fonplata, tendo, em 2007, participação de $31,25 \%$ e $35,63 \%$, respectivamente.

No que diz respeito à IIRSA, o Fonplata tem participado ativamente, desde o início, nas atividades dessa iniciativa, sendo esse fundo membro do Comitê de

\footnotetext{
${ }^{38}$ Isto é, o Brasil tem um terço, Argentina também, um terço, e os outros três países, juntos, mais um terço. Os aportes são efetuados $50 \%$ em dólares norte-americanos e $50 \%$ em moedas dos respectivos paísesmembros, sob cláusulas de ajuste das paridades com o dólar. Os aportes de Argentina e Brasil se efetuam em um prazo de três anos, enquanto de Bolívia e Uruguai em um prazo de dez anos e em quotas proporcionais.
} 
Coordenação Técnica da IIRSA no BID e na CAF. De fato, os projetos da IIRSA redimensionaram o papel do Fonplata no fomento do desenvolvimento e da integração entre os países pertencentes à bacia do Rio da Prata. Adicionalmente, esse fundo tem colaborado significativamente com a elaboração dos expedientes dos projetos, a organização da informação coletada, a elaboração de base de dados, bem como com o desenvolvimento de documentos técnicos (Fonplata, 2008).

É nessa perspectiva que se deve ter em mente o aumento de tamanho desse fundo, a partir de 2004 e até 2008 , do ponto de vista de todos os indicadores patrimoniais. O capital do Fonplata, que em 2004 era de US\$ 350 milhóes, aumentou consecutivamente de 2006 a 2008 chegando a US\$ 411 milhôes, que representa aumento de cerca de $17 \%$ em cinco anos. $\mathrm{O}$ ativo total, por sua vez, era de US\$ 391 milhóes, em 2004, aumentando para US\$ 452 milhóes em 2008 - crescimento de cerca de $15 \%$. A carteira de empréstimos, por sua vez, também cresceu ao longo do período 2004-2008: US\$ 421 milhões, em 2008, contra US\$ 194 milhôes apresentados, em 2004.

Deve-se ainda apontar a presença, na região, de uma instituição financeira multilateral sub-regional que se enquadra nas características de um banco de desenvolvimento: a Corporação Andina de Fomento (CAF). Sua origem se atrela à intençâo de fomentar e impulsionar a integração da regiấo andina. Esse processo iniciou-se em 1966, e em 1967 foi assinada a Declaração de Bogotá, na qual se estabelecia a coordenação das políticas comercial, industrial, financeira e em serviços de cooperação técnica. No entanto, foi o Acordo de Cartagena, aprovado em 1969, que efetivamente estabeleceu o marco político para o atrelamento de um organismo financeiro a um acordo de integração regional, qual seja, a Aladi. Ao longo dos anos, a CAF aumentou sua abrangência na região e se consolidou como o principal instrumento financeiro da integração andina. Essa instituição começou a operar com um capital autorizado de US\$ 100 milhóes e pago de US\$ 25 milhões.

No que se refere aos sistemas financeiros, esse organismo tem avançado no apoio a políticas do setor financeiro, com o objetivo de fazer os países alcançarem melhores práticas em seus sistemas de supervisão e maior desenvolvimento de seus mercados de capitais. Dessa forma, a CAF procura promover o Desenvolvimento e a Integraçáo dos Mercados Financeiros para contribuir com o fortalecimento dos sistemas de regulação e supervisão bancárias, e dos mercados de capitais mercados esses ainda pouco desenvolvi- 
dos nos países do Mercosul, como tratado na primeira seção deste trabalho. ${ }^{39}$

O total do capital subscrito da CAF em 2008 era de US\$3,2 bilhóes, sendo US\$2,2 bilhóes efetivamente integralizados (pagos). O capital pago é distribuído entre os acionistas, de modo que os principais acionistas da CAF são: Colômbia, Peru e Venezuela - 23,58\%, 23,67\% e $23,67 \%$ do capital, respectivamente. Essa participação dos acionistas no capital é condizente com o estabelecido no Convênio Constitutivo desse banco regional, segundo o qual Bolívia, Colômbia, Equador, Peru e Venezuela são países acionistas de Série "A" e "B", enquanto Argentina, Brasil, Chile, Costa Rica, Espanha, Jamaica, México, Panamá, Paraguai, República Dominicana, Trindade e Tobago e Uruguai são acionistas de série "C".

Em 2007, a carteira de créditos dessa instituição era de US\$ 9,6 bilhóes e, em 2008, alcançou a cifra de US\$10,26 bilhões, ou seja, aumento de 7\%. Indica, assim, a trajetória expansionista da CAF, uma vez que, em 2004, a carteira de crédito dessa instituição era de US\$ 7,22 bilhões.

Os países com maior participação na carteira de empréstimos da CAF, no período 2004-2008, foram: Peru (20,6\%), Colômbia (20\%), Equador (18,7\%), Venezuela $(16 \%)$ e Bolívia $(11,96 \%)$. O Bra- sil teve sua participação na carteira de empréstimos aumentada ao longo do período em tela, uma vez que, em 2004, participava com $4,12 \%$ e, em 2008 , passou a ter participação de $8 \%$. Algo semelhante deu-se com a Argentina, que aumentou sua importância ao longo do período em análise, tendo em 2008 participação de 6,7\%.

Os países que mais se beneficiaram com o desembolso, também no período 2004-2008, foram Peru (25,07\%), Colômbia (20,97\%), Equador (16,86\%), Brasil (11,70\%) e Venezuela (9,82\%). A média anual de desembolsos para o período foi de US\$ 3,56 bilhões, e a média por país foi de US\$1,37 bilhóes. Como se nota, a maioria dos contratos de empréstimo é firmada com os países acionistas das séries "A" e "B".

Desde meados dos anos 1990, a CAF tem avançado significativamente na função de provedora de recursos de médio e longo prazos. Conforme Sagasti e Prada (2006), os empréstimos de longo prazo, no período 1991-2000, representavam cerca de $50 \%$ do total aprovado, ao passo que, no período 2001-2003, aumentaram para $80 \%$. No período 20042008, a CAF continuou seu avanço como provedora de recursos de longo prazo, os quais, em 2008, representaram em média $85,13 \%$ do total de empréstimos conce-

\footnotetext{
${ }^{39}$ Baseado em informações do site da CAF. Disponível em: <http://www. caf.com/view/index. asp?ms=17\&pageMs=35515>. Acesso em: 13 out. 2009.
} 
${ }^{40}$ É importante destacar que essa comparação não deve ser feita sem mediaçóes, levandose em conta a ampla gama de instrumentos que compreende os ativos dos sistemas bancários. As fontes desses dados foram, respectivamente, Banco Central do Brasil - 50 maiores bancos; Banco Central da República da Argentina - Informe sobre Bancos; Banco Central do Paraguai - Boletines Estadísticos; e Banco Central do Uruguai - Reporte de Estabilidad Financiera. didos por esse organismo. A concessão de financiamentos para a execução de projetos em áreas estratégicas para a América do Sul foi a tônica do período em tela. Destaca-se a participação expressiva na carteira dos financiamentos aos setores de Transporte/Armazenamento e Telecomunicações (31\% em 2008) e de Eletricidade/Gás/Água (19,5\% em 2008). Esse quadro da distribuição dos recursos entre os setores condiz com os programas estratégicos adotados pela CAF, entre os quais estão a Iniciativa para a Integração da Infra-Estrutura Regional Sul-Americana (IIRSA) e o Apoio ao Desenvolvimento da Integração Fronteiriça (PADIF).

Os indicadores patrimoniais ilustram a expansão da CAF, sobretudo a partir de 2003. Em 2008, a carteira de empréstimos e de inversóes foi cerca de $44 \%$ superior a 2004. O capital pago dá suporte para tal expansão, haja vista o aumento de $45 \%$ em 2008, relativamente a 2004, vale dizer, de US\$1,49 bilhão para US\$ 2,17 bilhóes. Comparativamente às demais instituições financeiras multilaterais em operação caracterizadas anteriormente neste trabalho, a CAF é a maior em termos de capacidade financeira: em 2008, o ativo total era de US\$ 14,27 bilhóes, e o patrimônio líquido, de US\$ 4,55 bilhóes. A título de comparação, vale lembrar o total de ativos dos sis- temas bancários dos países do Mercosul. Naquele mesmo ano, 2008, os ativos do sistema bancário do Brasil somavam US\$ 1,4 trilhão; os da Argentina, US\$ 101 bilhôes; os do Paraguai, US\$ 4,4 bilhóes; e os do Uruguai, US\$ 17,37 bilhóes. ${ }^{40}$ Nesse sentido, é possível afirmar que sua participação na região, em termos de volume de ativos, não é inexpressiva, sendo relativamente mais importante para as economias de menor porte e que contam com sistemas financeiros menos profundos e estruturados, sobretudo no que diz respeito à moblizaçâo de funding de longo prazo. Ademais, vale apontar que, desde a década de 1990, tem disponibilizado aos seus sócios fundos em volumes compatíveis aos mobilizados pelo Banco Mundial.

Esses indicadores demonstram a importância desse banco sub-regional de desenvolvimento para a regiāo. Além disso, a análise realizada ao longo desta seção evidenciou que a concessáo de empréstimos de longo prazo pela CAF tem aumentado, assim como aquelas destinadas a setores ligados à criação de infraestrutura regional, sobretudo. Os países do Mercosul, nos últimos anos, alcançaram maior espaço na CAF, como demonstraram as carteiras de empréstimos e as aprovaçóes, bem como o aumento de capital que realizaram. 


\section{4_Considerações finais}

A discussão apresentada acima evidencia um movimento de aprofundamento da cooperação financeira em âmbito regional, especialmente dentro do Mercosul, estreitando o processo de integração e apontando para uma inflexão relativamente ao sentido que esse processo de integração regional apresentava ao longo da década de 1990. Na perspectiva da cooperação financeira, acordos para compensação de transaçôes comerciais, fundos de reserva e bancos e fundos regionais, ao mesmo tempo em que melhoram as condições de financiamento questáo absolutamente crucial do ponto de vista da análise keynesiana -, reduzem a vulnerabilidade externa e a instabilidade macroeconômica.

A análise dos sistemas financeiros dos países do Mercosul mostrou, em primeiro lugar, conexão evidente entre vulnerabilidade externa, instabilidade macro e fragilização dos sistemas financeiros, sobretudo nos casos de Argentina, Paraguai e Uruguai. Uma conexão táo estreita entre as crises externas e financeiras ocorreu em função de esses sistemas serem amplamente liberalizados. Em segundo lugar, foi possível observar nesses sistemas elementos comuns, assim como importantes assimetrias. Entre os elementos comuns, destacam-se: (i) abertura e libe- ralizaçáo financeiras (ii) importantes processos de fragilização dos sistemas financeiros, os quais, com exceçáo do Brasil, significaram crises bancárias; (iii) preponderância do mercado de crédito relativamente do mercado de capitais, quase inexistente em alguns dos países, mesmo após a abertura externa; (iv) importância da participação das instituiçóes financeiras públicas. Entre as assimetrias, podem-se ressaltar as enormes disparidades de tamanho, organizaçáo e complexidade dos sistemas.

A análise evidenciou também ou a inexistência ou a insuficiência de mecanismos de financiamento de longo prazo nos países do bloco, o que é um ponto de extrema gravidade. Enquanto o Uruguai e sobretudo o Brasil apresentam mecanismos de financiamento de longo prazo mais estruturados e importantes (ainda que certamente não suficientes), centrados em bancos e/ou fundos públicos, não se vê o mesmo nos sistemas financeiros da Argentina e do Paraguai. Na verdade, tal como apontado no trabalho, a abertura e a liberalização desses mercados - menos exacerbada no Brasil do que nos outros países do bloco - não foram capazes de viabilizar mecanismos de financiamento privado de longo prazo, o que aponta, mais uma vez, para a importância das instituiçóes regionais de finan- 
ciamento. Tampouco, como também se observou, de concorrer para a maior estabilidade desses sistemas financeiros. Antes o contrário.

Sobre as instituições financeiras analisadas, as evidências indicam terem sido essas, de forma geral, bem-sucedidas em sua atuação. Cabe aqui recuperar o que foi destacado no texto, isto é, a importância da atuação do CCR e do FLAR quando dos períodos de escassez de divisas e crises externas. Cabe apontar novamente para a importância relativa do Fonplata no financiamento da infraestrutura, tendo em consideração a carência de funding de longo prazo em grande parte dos países da região. E o mesmo vale, mas com importância ainda maior, dado o volume de recursos que mobiliza, para a CAF, a qual vem concentrando progressivamente seus desembolsos em recursos de longo prazo. Tais evidências apontam para a necessidade de ampliar e tornar mais eficiente essa atuação, através de maior coordenação entre as instituiçóes e de ampliação de sua capacidade de ação, no sentido de permitirem uma "defesa" mais eficaz contra as crises externas, ao mesmo tempo em que viabilizam aprofundamento da integração no plano produtivo e da infraestrutura.

Com base nas evidências arroladas e discutidas neste trabalho, concluímos que, nos últimos anos, floresceram iniciativas de cooperação financeira, ao mesmo tempo em que foram reforçadas instituições já existentes. Entendemos que o fortalecimento dessas iniciativas regionais, no âmbito de um aprofundamento ainda maior da cooperação, ao viabilizar a obtenção de financiamento de longo prazo para projetos de investimento e de infraestrutura regional e reduzir o grau de vulnerabilidade externa e instabilidade macroeconômica, fortalece os próprios acordos regionais e impulsiona o desenvolvimento dessas economias. 


\section{Referências bibliográficas}

ABOAL, D. et al. El sistema financiero uruguayo y la integración financiera em el Mercosur. In: FANELLI, J. (Org.). Mercosur: integración y profundización de los mercado financieros. Montevidéu: Red Mercosur de Investigaciones Económicas, 2008.

AGOSIN, M. R. Fortaleciendo la institucionalidad financiera en Latinoamérica. In: OCAMPO, J. M; UTHOFF, A. (Orgs.). Gobernabilidad e integración financiera: Ámbito global y regional. Santiago do Chile: Cepal, out./2004. 215-249 p.

AGOSIN, M. R. Strengthening regional financial cooperation. Revista da CEPAL, n. 73, Santiago do Chile, p. 30-50, 2001.

AGOSIN, M. H. 2011. Hacia un Fondo Monetario Latinoamericano. FLAR. Papers and Proceedings of the 2010 Conference of Economic Studies, published in March 2011, pp. 69102, available at: https://www. flar.net/contenido/contenido. aspx?catID $=152 \&$ conID $=2592$
AMADO, A. M.; SILVA, A. S. da. Consideraçôes sobre o processo de integração monetáriofinanceira do Mercosul. Estudos Econômicos, São Paulo, v. 30, n. 4, p. 571-596, out./dez. 2000.

\section{BANCO CENTRAL DO}

URUGUAY. Informe de Política Monetária - Quarto trimestre. BC Uruguay, Montevidéu, 2003. Disponível em: <http//www. bcu.gub.uy/autoriza/pepmam/ pmam04i1204.pdf>. Acesso em: junho de 2009.

BARRETO, P. Dólar: queda ou trauma passageiro. Desafios do Desenvolvimento. IPEA, Ano 6, n. 53, 2009.

BAUMANN, Renato. Integração regional e desenvolvimento econômico com referência a Celso Furtado. CEPAL Brasil: Brasília, ago. 2005.11 p.

BCB. Relatório de estabilidade financeira. 2008.

BCP (2008a). Balance del Sistema Bancario del Paraguay. Superintendencia de bancos, Intendencia de Análisis Financiero y Normas.

BCP (2008b). Boletines Estadísticos, dezembro de 2008.
BCU. Boletin de Situación y

Resultados, dec. 2008.

BCU. Reporte de Estabilidad

Financiera, dec. 2008.

BIANCARELI, A. M. Inserção externa e financiamento: Notas sobre padrôes regionais $\mathrm{e}$ iniciativas para a integração na América do Sul. Campinas, 2008. (mimeo).

CARVALHO, C. E. Integração financeira da América do Sul: passos importantes, muitas dificuldades. São Paulo, 2009. (mimeo).

CARVAlHO, F. J. C. de et al. Banking in Latin America. In: BERGER, A. et al. (Ed). Oxford Handbook of Banking. Oxford: Oxford University Press, 2010.

CCR. Relatório sobre a Compensação Multilateral de Saldos. Montevidéu: CCR, 2008.

CCR. Relatório sobre a Compensação Multilateral de Saldos. Montevidéu: CCR, 2009.

COUTO, L. F. O horizonte regional do Brasil e a construção da América do Sul. Revista Brasileira de Política Internacional, v. 50, n. 1, p. 159-176, 2007.
COUTO, L. F. Política externa brasileira para a América do Sul: As diferenças entre Cardoso e Lula. Civitas, Porto Alegre, v. 10, n. 1, p. 23-44, jan./abr. 2010.

CULPEPER, R. Reforma de la arquitetura financiera mundial: El potencial de las instituciones regionales. In: OCAMPO, José Antonio (Org.). Cooperación Financiera Regional. Santiago do Chile: Livros da Cepal, n. 91, p. 57-90, 2006.

CUNHA, A.; BICHARA. J.

Integração monetária e financeira em regiōes emergentes: $A$ experiência recente do Pacífico Asiático pode servir de inspiração para o Mercosul? Economia e Sociedade, Campinas, v. 14, n. 25, p. 235-262, 2005.

FANELLI, J. M. MERCOSUR: integración y profundización de los mercados financieros. In: FANELLI, J. M. (Coord.). $M E R C O S U R$ : integración y profundización de los mercados financieros. Montevidéu: Zonalibro, 2008. p. 11-38.

FARIA, J. A. E. O Mercosul: Princípios, finalidade e alcance do Tratado de Assunção. Brasília: MRE/SGIE/NAT, 1993. 193 p. 
FONPLATA. Memória Anual 2007. FONPLATA, Santa Cruz de la Sierra, 2008. Disponível em: <http://www.fonplata.org/ publicaciones/Publicaciones/ Memoria\%20Anual\%202007.pdf>.. Acesso em: maio de 2009.

KEYNES, J. M. A teoria geral do emprego, do juro e da moeda. Sáo Paulo: Atlas, 2003. 328 p.

MACHINEA, J. L.; TITELMAN, D. Less volatile growth? The role of regional financial institutions. Cepal Review, Santiago do Chile, n.91, p.7-28, abril/2007.

MENDONÇA, A. R. R. Fundo de Garantia do Tempo de Serviço: Gestão de recursos e papel de financiador das políticas de habitação e saneamento. II Encontro Internacional da Associaçāo Keynesiana Brasileira, Porto Alegre, 2009. 25 p.

MOLLO, M. L. R.; AMADO, A. M. Globalização e blocos regionais:

Consideraçóes teóricas e conclusôes de política econômica. Estudos Econômicos, São Paulo, v. 31, n. 1, p. 127-166, jan./mar. 2001.

MONTOYA, M. U. Perspectivas del fondo Latinoamericano de Reservas. Revista FLAR, Lima, n.3, p.7-18, 2007.

MOTTA VEIGA, P.; RÍOS, S. O regionalismo pós-liberal na América do Sul: origens, iniciativas e dilemas. Santiago: CEPAL (Serie Comercio Internacional 82), 2007. 48 p.
OCAMPO, J. A. La cooperación financiera regional: Experiencias y desafíos. In: OCAMPO, J. A. (Org.). Cooperación financiera regional. Santiago. Cepal (libros de la Cepal no. 91), 2006. p. 13-56.

PAULA, L. F.; ALVES Jr. The determinants and effects of foreign bank entry in Argentina and Brazil: A comparative analysis. Investigacion Económica, Facultad de Economía de la Universidad Nacional Autónoma de México, n. 259, p. 63-104, 2007.

PAULA, L. F.; FERRARI, F.; SOBREIRA, R.; FARIA, A. F.; SARAIVA, P.; GOMES, A. Mercado de títulos de dívida brasileiro no período 1995-2008: Causas e determinantes da evolução recente. Projeto de Estudos sobre as Perspectivas da Indústria Financeira Brasileira e o Papel dos Bancos Públicos. Convênio BNDES/FECAMP/CECON-IEUNICAMP/IE-UFRJ, 2009. 92 p.

PRATES, D.; CINTRA, M. A. M. Keynes e a hierarquia de moedas: Reflexóes sobre os regimes cambiais dos países periféricos. I Encontro Internacional da Associação Keynesiana Brasileira, Campinas-São Paulo, 2008. 20 p.

PRATES, D.; BIANCARELI, A. Panorama do ciclo de crédito recente: Condicionantes e características gerais. Projeto de Estudos sobre as Perspectivas da Indústria Financeira Brasileira e o Papel dos Bancos Públicos. Convênio BNDES/FECAMP/ CECON-IE-UNICAMP/IE-UFRJ, 2009. $61 \mathrm{p}$.
SÁEZ, S. La integración en busca de un modelo: los problemas de convergencia en America Latina y Caribe. CEPAL - División de Comercio Internacional e Integración, Santiago do Chile, julho/2008, 49p.

SANTANA, C. H.; KASAHARA, Y. Os limites da integração financeira e políticas de crédito na América do Sul: um novo modelo de desenvolvimento regional? Observador on-line, v.1, n. 5, jul.2006. Disponível em: http://observatorio.iuperj.br. Acesso em setembro de 2008.

SOUZA, A. M. et al. Integrando desiguais: Assimetrias estruturais e políticas de integração no Mercosul. IPEA: Texto para Discussão no 1.477. Rio de Janeiro, mar. 2010. 49 p.

STUDART, R.; HERMAN, J.

Estrutura e operaçóes dos sistemas financeiros no Mercosul: Perspectivas a partir das reformas institucionais dos anos 1990.

Texto para Discussão n. 799, IPEA, Brasília, 2001.

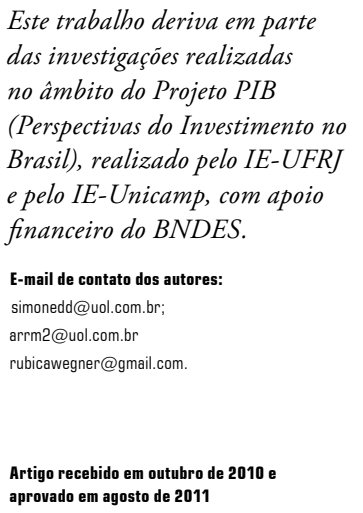


